\title{
RURAL HOUSEHOLDS' PERCEPTION OF VITAMIN A BIOFORTIFIED CASSAVA AND ITS PRODUCTS: IMPLICATIONS FOR FOOD SECURITY
}

\author{
Dorcas Lola ALABI ${ }^{1, *}$, Damilola Leah ARIBIFO', \\ Oluwatomiwo Elizabeth OLUYEMI ${ }^{1}$ \\ *E-mail: alabidorcas@yahoo.com
}

Received: Aug. 25, 2020. Revised: Nov. 20, 2020. Accepted: Dec. 22, 2020. Published online: Jan. 29, 2021

\begin{abstract}
The paper examined the perception of rural households about vitamin A biofortified cassava and its products in Osun State, Nigeria. Multistage sampling procedure was used to select 50 households' members. Quantitative data were collected on the respondents' personal and socioeconomic characteristics, their awareness on vitamin A biofortified cassava, their perception about the crop and its products, as well as the constraints affecting its acceptability in the study area. Data were described using frequency counts, percentages, means and standard deviation and inferential statistics, like Pearson Product Moment Correlation and Chi-square analyses. Results showed that the respondents had a mean age of 52.62 \pm 14.30 , while $82 \%$ of them were married. $74 \%$ of the respondents had heard of Vitamin A bio fortified cassava, 64\% had seen it while $44 \%$ had planted it with $54 \%$ having positive perception towards the crop and its products. Poor transport facilities $($ mean $=3.16)$ and difficulties in
\end{abstract}

getting planting materials (mean $=2.36$ ) ranked highest among the constraints affecting acceptability of the crop in the study area. There exist significant association between the respondents' marital status and their perception about vitamin A biofortified cassava. It was concluded that majority of the respondents have positive perception towards vitamin A biofortified cassava and its products. It was recommended that extension personnel should create more awareness about the nutritional value of the crop and its products to enhance better food security status among rural households.

Keywords: socio-economic; acceptability; awareness; constraints.

\section{INTRODUCTION}

Cassava (Manihot esculenta Crantz) is one of the world most important food crops (Nwokoro et al., 2013; Asogwa et al., 2013, cited in

\footnotetext{
1 Department of Agricultural Extension and Rural Development, Obafemi Awolowo University, lle-Ife, Osun State, Nigeria
} 
Obayelu et al., 2018) with a total output of over 277 million tonnes in 2016 against 71 million metric tonnes in 1961 (FAO, 2018). It is very tolerant of drought and heat stress and produces well on marginal soils (Kenneth, 2011, cited in Ekwere et al., 2014). According to the International Fund for Agricultural Development (2013), Africa is one of the continents of the world where about 600 million people are dependent on cassava for food. Nigeria produces more than half of the total cassava output in the world (Obayelu et al., 2018), making the nation the largest world producer, a third more than production in Brazil and almost double the production of Indonesia and Thailand (FAO, 2004). Wole-Alo and Okunlola (2015) reiterated that cassava production is vital to the economy of Nigeria as the world's largest producer of the commodity with a total annual production of about 60 million tonnes (FAOSTAT, 2019). It has also been ascertained that cassava generates billions of incomes for households and government, as well as contributing significantly to food security at various levels (FAO, 2012, cited in Flibert et al., 2017).

After rice and maize, cassava is the third most important food crop in terms of carbohydrate source providing more than $60 \%$ of the daily calorie needs of the populations in tropical Africa and Central America (Kobawila, 2005). In Nigeria, it is one of the foods mostly consumed (International Institute of Tropical Agriculture, 2010; Kenneth 2011). It is a versatile food security crop with the root serving as a good source of carbohydrates when processed into variety of products including gari, fufu, flour, tapioca and beverages for human consumption and cassava chips for animal feed (Kenneth, 2011), as well a source of bio-fuel (Adekanye et al., 2013).

Malnutrition is a devastating problem, especially among the resource poor rural households in Nigeria. The causes of malnutrition are not limited to lack of basic protein and energy, but also include lack of micronutrients, such as vitamin A, iodine, and iron. Nutrition-Federal Ministry of Health (2014) reported that almost $63 \%$ of women are anaemic and $31 \%$ are iodine deficient, while close to $30 \%$ of under-fives is vitamin A deficient. According to MaziyaDixon et al. (2007) and World Health Organizations (2017), Vitamin A deficiency can cause severe night blindness and high mortality rate in pregnant women. It has been observed that many Nigerians irrespective of age, gender and geographical location, get less Vitamin A than the required amount and that malnutrition is concentrated in the rural areas of Nigeria and primarily affects poor women and children. Therefore, improving the nutrition of the rural people is necessary because only better-nourished citizens can participate more effectively in the labour force (Kumar and Quisumbing, 2010).

Bio-fortification involves the use of traditional crop breeding 


\section{D.L. ALABI, D.L. ARIBIFO, O.E. OLUYEMI}

techniques or modern biotechnology to produce staple crops that are micronutrient dense (Shanshan et al., 2010) in order to reduce micronutrient deficiencies (Rubino et al., 2012). International research effort on biofortification has focused on three micronutrients namely; iron, zinc and vitamin A (Oparinde et al., 2012). The attention is on regular daily intake of consistent and large amount of staple foods consumed by all household members and, since staple foods are predominant in the diets of the poor, biofortification implicitly targets lowincome households (Nestel et al., 2006). In view of this, plant breeders have been working to develop biofortified cassava since the crop has been a major staple food in Nigeria for decade. In 2011, the national committee on naming, registration and release of crop varieties in Nigeria released officially three improved pro-vitamin A cassava varieties (Oparinde et al., 2012). These varieties were bred using conventional breeding methods to contain higher concentrations of beta-carotene (provitamin A), which account for the yellow colour of the varieties, while the white or cream cassava varieties contain either no carotenoids or very low levels of carotenoids that cannot significantly contribute to human health (Oparinde et al., 2012). The pro-vitamin A (beta-carotene) in the roots of the yellow cassava varieties is capable of addressing the problem of vitamin A deficiency among Nigeria growing population (Ayinde et al., 2017). With biofortification, farmers are empowered to proffer solution to the problem of vitamin A deficiency because after satisfying their household's food needs, the surplus biofortified crops will be sold into rural and urban retail outlets. Studies have shown that the new yellow cassava (biofortified cassava) can provide up to $25 \%$ of daily recommended vitamin A intake of consumers (HarvestPlus, 2017). Since cassava constitutes a main part of many people's diets in Nigeria, introducing vitamin A biofortified cassava is expected to be an excellent innovation for large scale health improvement and achievement of the millennium development goal of reducing the under-five child mortality and maternal mortality ratio significantly.

Based on the above, International Institute of Tropical Agriculture (IITA), Ibadan released the cuttings of vitamin A biofortified cassava varieties, which was disseminated to farmers in the study area by the extension service providers of the Integrated Rural Development Programme (IRDP) of the Obafemi Awolowo University, Ile-Ife, Nigeria. It was observed that farmers readily accepted and adopted the production technologies of these new varieties of cassava at introduction, but after a while there was discontinuance. Perception of people about a particular innovation may influence the adoption and continuity or otherwise of such innovation as Meijer et al. (2015) observe that perception is one of the major intrinsic factors that influence 
decision of an individual to adopt any innovation. However, there is dearth of information on the perception of rural households in the study area on the vitamin A biofortified cassava and its utilisation, hence this study.

\section{Objectives of the study}

The main objective of this study was to examine the perception of respondents about vitamin A biofortified cassava and its products among rural households in Osun State, Nigeria. It specifically described the personal and socioeconomic characteristics of the respondents, examined their awareness about the crop and its products, and examined the perceived constraints affecting the acceptability of vitamin A biofortified cassava and its products in the study area.

\section{Hypothesis of the study}

There is no significant relationship between the personal and socio-economic characteristics of the respondents and their perception about vitamin A biofortified cassava.

\section{MATERIALS AND METHODS}

The study was conducted in Osun State, Nigeria. The population of the study was the rural households in the beneficiary communities of the Integrated Rural Development Programme (IRDP), the outreach programme of the Obafemi Awolowo University, Ile-Ife, Nigeria. IRDP is covering about 50 rural communities, which have been zoned into four Strategic Training and Development Centres (STDCs) for ease of operation. The STDCs are named after the zonal headquarter communities namely:
Iyanfoworogi STDC for Ife zone, Esa-oke STDC for Ijesa zone, Oojo STDC for Ede zone and Elefon STDC for the university zone. Multi-stage sampling procedure was used to select the respondents for the study. At the first stage, $50 \%$ (2) of the STDCs were randomly selected namely Iyanfoworogi and Elefon. At the second stage, two communities each were selected from the two selected STDCs making a total of four communities, namely Isoya and Erefe from Iyanfoworogi STDC, as well as Elefon and Oke-Ake from Elefon STDC. The last stage involved proportionate random selection of $15,12,12$, and 11 households from Isoya, Erefe, Elefon and Oke-Ake communities, respectively, from which one member (respondent) each was selected to give a total of 50 respondents.

\section{Measurement of variables}

Perception of rural households about vitamin A biofortified cassava and its products was the dependent variable for the study. It was measured by asking respondents to indicate whether they, Strongly Agreed, Agreed, Undecided, Disagreed or Strongly Disagreed to 12 perceptional statements scoring from 5 points to 1 point, respectively, for the positive statements and vice versa for the negative statements. The total maximum and minimum perception scores were 60 and 12 , respectively. Equal interval was used to categorise respondents to positive, negative and indifferent perception. Awareness of the respondents about biofortified cassava was measured by asking respondents to indicate whether they have heard, seen, planted, processed and consumed vitamin A biofortified cassava before or not. The constraints affecting the acceptability of vitamin A biofortified cassava and its products in the study area were investigated by asking respondents to indicate the constraints and 
the extent to which they affect the acceptability of vitamin A biofortified cassava and its products whether Very Much (3), Much (2), A little (1) and Not at all (0). The maximum attainable score was 48 while the minimum attainable score was 0 . The cut-off point of 1.5 (i.e. $3+2+1+0 \div 4=1.5$ ) was used to categorise the constraints to severe and not severe.

\section{RESULTS AND DISCUSSION}

\section{Personal and socio-economic characteristics of the respondents}

Table 1 reveals that about onequarter $(26 \%)$ of the respondents were between 29 and 41 years, meanwhile about one-third (32\%) were between 42 and 54 years, with the mean age of $52.62 \pm 14.30$ years. This implies that respondents were mostly adults, which could have acquired relevant experiences on different farm enterprises including cassava. This finding agrees with Awotide et al., (2011), that as farmers age, they gain more experience, which could enhance their productivity and managerial ability. More male (52\%) respondents than female (48\%) were involved in cassava enterprise. This is in line with Afolami et al. (2015), who reported that more males were involved in farming, which could be due to the tedious nature of farming in Nigeria. Majority (82\%) of the respondents were married. Marriage implies increase responsibility, which may necessitate their involvement in different farming enterprises. This finding is in line with Abdoulaye et al. (2012), who posited that majority of farmers in their study area were married, which invariably results in them having family responsibilities that presupposes their willingness to get involved in productive activities to meet their household needs. Furthermore, the results in Table 1 show that majority (70\%) had between 3-6 persons in their households, while some (24\%) had between 7-10 persons in their households with the mean household size of $6 \pm 2$ persons. This implies that rural households are now of moderate size, unlike before when they used to be very large. In terms of ethnicity, many (56\%) of the respondents were Yorubas, while some $(28 \%)$ were Igbos and few (16\%) were from other ethnic groups like Edo, Idoma and Gara. This is expected since the study area is predominantly a Yoruba ethnic region of Nigeria.

Many (62\%) of the respondents spent 7 years and above in acquiring formal education, which is expected to influence their level of awareness, perception and acceptability of vitamin A biofortified cassava and products. This is in line with Sofoluwe et al. (2011), that education influences people's perception and acceptability of innovations. It also agrees with Olatade et al. (2013), that farmers with one form of education or the other can comprehend with any innovation introduced to them. Respondents also engaged in multiple occupations with the majority $(90 \%)$ engaging in farming, $52 \%$ engaged in cassava processing, $26 \%$ were into trading and $14 \%$ were into handcraft 
job. This implies that majority of the respondents were farmers and primarily dependent on farming to earn a living. This is expected since the majority of rural populace in Nigeria are farmers. As regards monthly income from cassava processing and other occupations, the mean income from cassava processing was $\$ 7,380.00 \pm 11385.44$, while the mean income from other occupations was $\$ 33,160.00 \pm 34266.28$. The implication of this is that respondents had more monthly income from other occupations than from cassava processing. This could be an indication that most of the respondents processed cassava for household-consumption. The mean years of experience in cassava processing was $19.02 \pm 17.39$ indicating the opportunity to have acquired requisite knowledge, skills and experience in processing cassava into various food products. The finding is closer to that of Odediran and Ojebiyi (2017), who found that more than one-third $(35 \%)$ of the cassava processors in Southwest Nigeria had between 21 and 30 years of experience; $62 \%$ of the respondents got information about vitamin A biofortified cassava from extension agents, while $34 \%$ heard from friends and relatives. This implies that extension agents were the major channel for dissemination of information about vitamin A biofortified cassava in the study area.

Table 1 - Distribution of respondents by their personal and socio-economic characteristics $(n=50)$

\begin{tabular}{|c|c|c|c|c|}
\hline Variables & Frequency & $\%$ & Mean & S.D. \\
\hline \multicolumn{5}{|l|}{$\overline{\text { Age (Years) }}$} \\
\hline$\leq 28$ & 1 & 2.0 & & \\
\hline $29.00-41.00$ & 13 & 26.0 & & \\
\hline $42.00-54.00$ & 16 & 32.0 & 52.62 & 14.30 \\
\hline $55.00-67.00$ & 10 & 20.0 & & \\
\hline $68.00+$ & 10 & 20.0 & & \\
\hline \multicolumn{5}{|l|}{ Sex } \\
\hline Male & 26 & 52.0 & & \\
\hline Female & 24 & 48.0 & & \\
\hline \multicolumn{5}{|l|}{ Marital status } \\
\hline Single & 2 & 4.0 & & \\
\hline Married & 41 & 82.0 & & \\
\hline Divorced & 1 & 2.0 & & \\
\hline \multicolumn{5}{|l|}{ Household size } \\
\hline$\leq 2.00$ & 1 & 2.0 & & \\
\hline $3.00-6.00$ & 35 & 70.0 & 5.86 & 2.23 \\
\hline $7.00-10.00$ & 12 & 24.0 & & \\
\hline $11.00+$ & 2 & 4.0 & & \\
\hline \multicolumn{5}{|l|}{ Ethnicity } \\
\hline Igbo & 14 & 28.0 & & \\
\hline Yoruba & 28 & 56.0 & & \\
\hline Edo, Idoma \& Gara & 8 & 16.0 & & \\
\hline
\end{tabular}




\begin{tabular}{|c|c|c|c|c|}
\hline \multicolumn{5}{|c|}{ Number of years spent in formal education } \\
\hline$\leq 1.00$ & 4 & 8.0 & & \\
\hline $2.00-6.00$ & 15 & 30.0 & 9.36 & 4.79 \\
\hline $7.00-11.00$ & 9 & 18.0 & & \\
\hline $12.00+$ & 22 & 44.0 & & \\
\hline \multicolumn{5}{|l|}{ *Occupation } \\
\hline Farming & 45 & 90.0 & & \\
\hline Cassava processing & 26 & 52.0 & & \\
\hline Trading & 13 & 26.0 & & \\
\hline Civil servant & 2 & 4.0 & & \\
\hline Hand craft & 3 & 6.0 & & \\
\hline \multicolumn{5}{|c|}{ Years of farming experience } \\
\hline$\leq 10.00$ & 12 & 24.0 & & \\
\hline $11.00-20.00$ & 15 & 30.0 & & \\
\hline $21.0-30.00$ & 9 & 18.0 & 24.12 & 16.02 \\
\hline $31.00-40.00$ & 7 & 14.0 & & \\
\hline $41.00-50.00$ & 4 & 8.0 & & \\
\hline $51.00+$ & 3 & 6.0 & & \\
\hline \multicolumn{5}{|c|}{ Monthly income from cassava processing ( $\$$ ) } \\
\hline$\leq 5000.00$ & 31 & 62.0 & & \\
\hline $5001.00-20000.00$ & 15 & 30.0 & 7380.00 & 11385.44 \\
\hline $20001.00-35000.00$ & 2 & 4.0 & & \\
\hline $35001.00+$ & 2 & 4.0 & & \\
\hline $5001.00-70000.00$ & 42 & 84.0 & 33160.00 & 34266.28 \\
\hline $70001.00-135000.00$ & 4 & 8.0 & & \\
\hline \multicolumn{5}{|c|}{ Years of experience in cassava processing } \\
\hline$\leq 5.00$ & 16 & 32.0 & & \\
\hline $6.00-16.00$ & 12 & 24.0 & & \\
\hline $17.00-27.00$ & 6 & 12.0 & 19.02 & 17.39 \\
\hline $28.00-38.00$ & 6 & 12.0 & & \\
\hline $39.00-49.00$ & 5 & 10.0 & & \\
\hline \multicolumn{5}{|c|}{ Monthly income from other occupation } \\
\hline$\leq 5000.00$ & 3 & 6.0 & & \\
\hline $5001.00-70000.00$ & 42 & 84.0 & 33160.00 & 34266.28 \\
\hline $70001.00-135000.00$ & 4 & 8.0 & & \\
\hline $135001.00+$ & 1 & 2.0 & & \\
\hline \multicolumn{5}{|l|}{ Sources of information } \\
\hline Extension agents & 31 & 62.0 & & \\
\hline Research institute & 2 & 4.0 & & \\
\hline Friends and relatives & 17 & 34.0 & & \\
\hline
\end{tabular}

$\%=$ percentage; S.D. = Standard deviation; ${ }^{*}$ Multiple responses; Source: Field survey, 2019.

Awareness of the respondents on vitamin $A$ biofortified cassava and its products

Results in Table 2 show that majority (74\%) of the respondents had heard about Vitamin A biofortified cassava, many (64\%) had seen it, while some $(44 \%)$ had planted the crop. Majority $(63.6 \%)$ of those that had planted the cassava before had stopped planting while only $36.4 \%$ of them were still planting. Among those 
that had discontinued planting, reasons such as non-availability of planting material $(85.7 \%)$, inadequate knowledge on processing $(71.4 \%)$ and lack of market opportunities for the fresh tubers $(71.4 \%)$ were indicated for discontinuance.

The results show further that only few $(28 \%)$ of the respondents had processed vitamin A biofortified cassava before and they indicated that they had processed it into products like gari $(100 \%)$, fufu $(50 \%)$ and lafun (28\%). The implication of this is that gari is the most important product of produced by cassava processors in the study area. Also, less than half $(36 \%)$ of the respondents had consumed bio-fortified cassava products before in forms of gari (100\%), fufu (44.4\%) and lafun $(33.3 \%)$. The findings imply that respondents were mainly aware about the crop production while their awareness on processing is very low. Also, that the adoption of both the production and processing technologies of the crop is low. This is in line with Ayinde and Adewumi (2016), who reported low level of adoption of vitamin A biofortified cassava in their study area.

\section{Perception of respondents on vitamin A bio fortified cassava and its products}

Results in Table 3 show that comparing the scale of measurement with each perceptional statement mean scores, it shows that respondents strongly agreed with the positive perceptional statements that consumption of vitamin A biofortified cassava products reduce the risk of illness and death (4.72), consumption of vitamin A biofortified cassava products can improve the health of children (4.72) and consumption of vitamin A biofortified cassava products can solve the problem of eye defect (4.70), while they also agreed with the statements that yellow cassava mature earlier than white cassava (3.90), yellow cassava has higher market price than white cassava varieties (3.82) and yellow cassava has low cyanide content (3.62).

On the other hand, they were indifferent to the negative perceptional statements that vitamin A bio-fortified cassava products are not original (3.28), vitamin A biofortified gari does not have good binding property (3.06), the yellow colour of the tuber is not acceptable to the local people (3.02), vitamin A biofortified cassava gari does not have a sour taste like white cassava gari (3.00) and yellow cassava has limited market value (2.94), while they agreed with the negative perceptional statement that yellow cassava cutting is not readily available (1.86), which is in line with the result in Table 5, that difficulties in getting planting materials was one of the major constraints that affect the acceptability of Vitamin A biofortified cassava and its products. 
Table 2 - Distribution of respondents by their awareness on Vitamin A biofortified cassava and its products $n=\mathbf{5 0}$

\begin{tabular}{|c|c|c|}
\hline Variables & Frequency & $\%$ \\
\hline \multicolumn{3}{|l|}{ Heard of vitamin A cassava before } \\
\hline No & 13 & 26.0 \\
\hline Yes & 37 & 74.0 \\
\hline \multicolumn{3}{|l|}{ Seen vitamin A cassava before } \\
\hline No & 18 & 36.0 \\
\hline Yes & 32 & 64.0 \\
\hline \multicolumn{3}{|l|}{ Planted vitamin A cassava before } \\
\hline No & 28 & 56.0 \\
\hline Yes & 22 & 44.0 \\
\hline \multicolumn{3}{|l|}{ If yes, are you still planting? } \\
\hline No & 14 & 63.6 \\
\hline Yes & 8 & 36.4 \\
\hline \multicolumn{3}{|l|}{${ }^{*}$ Reasons for discontinuance } \\
\hline Planting material not available & 12 & 85.7 \\
\hline Inadequate knowledge on processing & 10 & 71.4 \\
\hline No market for the fresh tuber & 10 & 71.4 \\
\hline No market for the processed products & 6 & 42.9 \\
\hline \multicolumn{3}{|c|}{ Processed Vitamin A biofortified cassava } \\
\hline No & 36 & 72.0 \\
\hline Yes & 14 & 28.0 \\
\hline \multicolumn{3}{|c|}{ *Products processed from Vitamin A cassava } \\
\hline Gari & 14 & 100.0 \\
\hline Fufu & 7 & 50.0 \\
\hline Lafun & 4 & 28.6 \\
\hline \multicolumn{3}{|c|}{ Consumed Vitamin A biofortified cassava } \\
\hline No & 32 & 64.0 \\
\hline Yes & 18 & 36.0 \\
\hline \multicolumn{3}{|l|}{ *Vitamin A cassava products consumed } \\
\hline Gari & 18 & 100.0 \\
\hline Fufu & 8 & 44.4 \\
\hline Lafun & 6 & 33.3 \\
\hline
\end{tabular}

${ }^{*}$ Multiple responses; Source: Field survey, 2019

Further analysis in Table 4 those with perception score of 41.51 shows the result of the overall and above were categorised as having perception scores of the respondents which was categorized into negative, indifferent and positive perception. Respondents with perception scores less than or equal to 14 were ranked as having negative perception $(2 \%)$, while those with perception scores between 29.00 and 41.50 were categorised as indifferent (44\%) and positive perception (54\%) towards vitamin A biofortified cassava and products. The implication of this finding is that large percentage of the respondents have positive perception towards vitamin A biofortified cassava and products, which may influence the acceptability and invariably the consumption of vitamin A biofortified 
cassava food products. The finding corroborates Meijer et al. (2015), that

perception can influence decision to adopt innovations.

Table 3 - Perception of respondents on Vitamin A biofortified cassava

\begin{tabular}{lll}
\hline Variables & Mean & S.D. \\
\hline Consumption of biofortified products reduces the risk of illness and death & 4.72 & 0.54 \\
\hline $\begin{array}{l}\text { Consumption of vitamin A biofortified products can improve the health of } \\
\text { children }\end{array}$ & 4.72 & 0.50 \\
\hline $\begin{array}{l}\text { Consumption of vitamin A biofortified products can solve the problem of } \\
\text { eye defect }\end{array}$ & 4.70 & 0.54 \\
\hline Yellow cassava matures earlier than white cassava & 3.90 & 1.04 \\
\hline Yellow cassava has higher market price than white cassava varieties & 3.82 & 1.14 \\
\hline Yellow cassava has low cyanide content & 3.62 & 0.88 \\
\hline Yellow colour of vitamin A biofortified food product is not natural & 3.28 & 1.29 \\
\hline Vitamin A biofortified cassava gari does not have good binding property & 3.06 & 1.54 \\
\hline The yellow colour of the tuber is not acceptable to the local people & 3.02 & 1.36 \\
\hline $\begin{array}{l}\text { Vitamin A biofortified cassava gari does not have a sour taste like that of } \\
\text { white cassava }\end{array}$ & 3.00 & 1.48 \\
\hline Yellow cassava has limited market value & 2.94 & 1.33 \\
\hline Yellow cassava cutting is not readily available & 2.86 & 0.95 \\
\hline Grand mean & $\mathbf{2 . 5 2}$ & \\
\hline
\end{tabular}

Strongly agreed (5), Agreed (4), Undecided (3), Disagreed (2), Strongly disagreed (1) for positive statements and vice versa for negative statements; Source: Field survey, 2019

Table 4 - Overall perceptions of the respondents on Vitamin A biofortified cassava $(n=50)$

\begin{tabular}{lccl}
\hline Perception score & Frequency & Percentage & Decision \\
\hline$\leq 14.00$ & 1 & 2.0 & Negative perception \\
\hline $29.00-41.00$ & 21 & 42.0 & Indifferent \\
\hline $42.00+$ & 28 & 56.0 & Positive perception \\
\hline
\end{tabular}

Source: Field survey, 2019

Constraints affecting acceptability of vitamin A biofortified cassava and products

Results in Table 5 show that with the cut-off point of 1.5, the most severe constraints affecting acceptability of vitamin A biofortified cassava and its products in the study area include poor transport facilities $($ mean $=3.16)$, difficulties in getting planting materials $($ mean $=2.36)$, lack of training on appropriate processing techniques $($ mean $=1.98)$, inadequate market (mean $=1.90)$, lack of appropriate technologies (mean = 1.84 ), high cost of adoption (mean = 1.80 ), lack of credit facilities (mean $=$ 1.78) and high cost of transportation $($ mean $=1.58)$. On the other hand, the less severe constraints include inadequate extension contact $($ mean $=$ 1.42), inadequate processing facilities (mean $=0.88)$, inadequate access to labour supply (mean $=0.76)$ and lack of storage facilities (mean $=0.64$ ). The findings imply that multiple constraints affect the acceptability of vitamin A biofortified cassava and its 
products in the study area, which should be addressed to enhance the acceptability of the crop. This is in line with Olayemi et al. (2018), who identified several constraints affecting the acceptability of improved cassava varieties in their study area to include high cost of transportation and lack of capital among others.

Table 5 - Constraints affecting the acceptability of Vitamin A biofortified cassava among processors $n=50$

\begin{tabular}{llll}
\hline Constraints & Mean & S.D. & Rank \\
\hline Poor transport facilities & 3.16 & 6.28 & $1^{\text {st }}$ \\
\hline Difficulties in getting planting materials & 2.36 & 0.88 & $2^{\text {nd }}$ \\
\hline Lack of training on appropriate processing techniques & 1.98 & 1.29 & $3^{\text {rd }}$ \\
\hline Inadequate market for raw tuber and products & 1.90 & 1.23 & $4^{\text {th }}$ \\
\hline Lack of appropriate processing technologies & 1.84 & 1.09 & $5^{\text {th }}$ \\
\hline High cost of adoption & 1.80 & 1.18 & $6^{\text {th }}$ \\
\hline Lack of credit facilities & 1.78 & 1.28 & $7^{\text {th }}$ \\
\hline High cost of transportation & 1.58 & 1.25 & $8^{\text {th }}$ \\
\hline Inadequate extension contacts & 1.42 & 1.18 & $9^{\text {th }}$ \\
\hline Inadequate processing facilities & 0.88 & 1.19 & $10^{\text {th }}$ \\
\hline Inadequate access to labour supply & 0.76 & 1.00 & $11^{\text {th }}$ \\
\hline Lack of storage facilities & 0.64 & 1.06 & $12^{\text {th }}$ \\
\hline
\end{tabular}

Grand mean $=2.02$; Cut-off point $=1.5$; Source: Field survey, 2019

\section{Testing of hypothesis}

There is no significant relationship between the personal and socio-economic characteristics of the respondents and the perception of respondents about vitamin A biofortified cassava and its products in the study area. Results of Pearson's Product Moment Correlation analysis in Table 6 show no significant relationship between respondents' perception and all the personal characteristics measured on ratio scale, while results of chi-square analysis in Table 7 show that only marital status of respondents $\left(\chi^{2}=50.388\right)$ has significant association with their perception at $p \leq 0.01$; hence the null hypothesis is accepted.

Table 6 - Pearson's product moment correlation analysis between socio-economic characteristics of respondents and their perception towards vitamin A biofortified cassava and products

\begin{tabular}{lccc}
\hline Variables & $\begin{array}{c}\text { Correlation } \\
\text { coefficient }(\boldsymbol{r})\end{array}$ & $\boldsymbol{p}$ - value & Decision \\
\hline Age & -0.002 & 0.989 & $\mathrm{NS}$ \\
\hline Number of years spent for formal education & -0.192 & 0.182 & $\mathrm{NS}$ \\
\hline Income from cassava processing & -0.028 & 0.845 & $\mathrm{NS}$ \\
\hline Income from other occupations & 0.001 & 0.997 & $\mathrm{NS}$ \\
\hline Years of farming experience & -0.015 & 0.915 & $\mathrm{NS}$ \\
\hline Years of experience in cassava processing & 0.009 & 0.953 & $\mathrm{NS}$ \\
\hline
\end{tabular}

NS = not significant; Source: Field survey, 2019 
Table 7 - Results of Chi-square showing association between socio-economic characteristics of respondents and their perception towards vitamin A biofortified cassava and products

\begin{tabular}{ccccc}
\hline Variables & $\mathbf{x}^{2}$-value & df & $\boldsymbol{p}$ - value & Decision \\
\hline Sex & 1.687 & 2 & 0.430 & NS \\
\hline Marital status & 50.388 & 3 & $0.000^{* *}$ & S \\
\hline Religion & 0.929 & 2 & 0.920 & NS \\
\hline Ethnicity & 3.816 & 4 & 0.431 & NS \\
\hline Occupation & 5.730 & 8 & 0.677 & NS \\
\hline Sources of information & 3.914 & 6 & 0.688 & NS \\
\hline Membership of association & 0.649 & 1 & 0.723 & NS \\
\hline
\end{tabular}

Source: Field survey, 2019; ${ }^{*}$ Significant at 0.01 ; NS = not significant; $\mathrm{df}=$ degree of freedom

The implication of the finding is that all the selected personal and socio-economic characteristics of the respondents investigated in this study, except their marital status, have nothing to do with their overall perception about vitamin A biofortified cassava and its products.

\section{CONCLUSIONS}

Based on the study, it was revealed that awareness about vitamin A biofortified cassava and its products is low among respondents, majority show favourable perception towards the crop, but multiple constraints limit its acceptability in the study area. These observations have implication for household food security in the study area in the sense that low awareness and limited acceptability of the crop will hinder eradication of hidden hunger in form of vitamin A deficiency in the study area. It is therefore recommended that extension personnel should intensify efforts in creating more awareness about the nutritional and health benefits of the crop, while identified constraints should be minimized by making planting materials readily available and organizing training for processors on appropriate processing techniques. The government should also provide easy access to credit facilities and subsidy on agro inputs needed to minimize the cost of adoption.

\section{REFERENCES}

Abdoulaye, T., Abass, A., Maziya-Dixon, B., Tarawali, G., Okechuckwu, R., Rusike, J., Alene, A., Manyong, V. \& Ayedun, B. (2012). Awareness and adoption of improved cassava varieties and processing technologies in Nigeria, J.Dev.Agric. Econ., 6(2): 67-75, DOI: 10.5897/JD AE2013.006

Adekanye, T.A., Ogunjimi, S.I. \& Ajala, A.O. (2013). An Assessment of Cassava Processing Plants in Irepodun Local Government Areas, Kwara State, Nigeria. World J.Agric. Res., 1(1): 14-17, DOI: 10.12691/wj ar-1-1-4

Afolami, C.A., Obayelu, A.E. \& Vaughan, I.I. (2015). Welfare impact of adoption of improved cassava varieties by rural households in South Western Nigeria. Agric. Food Econ., 3(1): 18, DOI: 10.1186/s401 00-015-0037-2

Asogwa, B.C., Ezihe, J.A.C. \& Ater, P.I. (2013). Socio-economic analysis of 
cassava marketing in Benue State, Nigeria. IJIAS, 2(4): 384-391.

Awotide, B.A., Abdoulaye, Alene T.A. \& Manyong, V. (2011). Socioeconomic factors and smallholder cassava farmers' access to credit in South Western Nigeria, Tropicultura, 37(1) DOI: 10.25518/2295-8010.262

Ayinde, O.E. \& Adewumi, M.O. (2016). Risk and adoption analysis of innovation in cassava production in Oyo state, Nigeria: A case study for vitamin A variety. World Congress on Root and Tuber Crops Nanning, Guangxi, China, January 18-22, 2016.

Ayinde, O.E., Adewumi, M.O., Ajewole, O.O. \& Ologunde, O.O. (2017). Determinants of adoption of vitamin A bio-fortified cassava variety among farmers in Oyo State, Nigeria. Croat.J. Food Sci.Technol., 9(1): 74-79, DOI: $10.17508 / C J F S T$. 2017.9.1.10

Ekwere, G.E., Edem, I.D. \& Agbasi, O.E. (2014). Adoption of root and tuber technologies among farmers (Agricultural Development Programme. Int.J.Environ., 3(4): 117-132, DOI: 10.4314/jae.v20i1.4

Food and Agriculture Organization (FAO) (2004). A cassava industrial revolution in Nigeria. The potential for a new industrial crop. Food and Agriculture Organization of the United Nations, Corporate Document Repository. Retrieved online in August, 12, 2017 from http://www.fao.org/docrep/007/y554 8e/y5548e00.htm\#Contents

FAO (2012). Food Outlook Global Market. Global Information and Early Warning System (GIEWS), FAO, Rome, November 2012, page 129: FAO.

FAO (2018). Food and Agriculture Organization Statistics: Production, Crops, Cassava, 2010 data. Retrieved online on 30 June, 2018 from: http://www.fao.org/faostat/en/ \#data/ QC
Food and Agriculture Organization of the United Nations (FAO) Statistical Database, Statistical Division (FAOSTAT) (2019).

Flibert, G., Koussao, S., Donatien, K., Hagretou, S., Yves, T. \& Aly, S. (2017). Origins, production, and utilization of cassava in Burkina Faso, a contribution of a neglected crop to household food security. Food Sci.Nutr., 5(3): 415-423, DOI: 10.1002/fsn3.408

HarvestPlus (2017). Biofortification Progress Brief. Washington, D.C. http://www.harvestplus.org/sites/defa ult/fies/Biofortifiation 2014 (accessed 21 August 2017).

International Fund for Agricultural Development (IFAD). (2013). Cassava: Turning a Subsistence Crop into a Cash Crop in Western and Central Africa, Rural Poverty Portal, BreadcrumbsPortlet, Powered by IFAD. Retrieved online June 23, 2016 from: http://www.fidafrique.net/ rubrique55 $4 . \mathrm{html}$

International Institute of Tropical Agriculture (IITA), (2010). Postharvest technology. Annual report. pp. 62-80.

Kenneth, V.A.R. (2011). Evaluation of three cassava varieties for tuber quality and yield. Gladstone Road Agricultural Centre Crop Research Report No. 4, p. 12.

Kobawila, S.C., Louembe, D., Keleke, S., Hounhouigan, J. \& Gamba, C. (2005). Reduction of the cyanide content during fermentation of cassava roots and leaves to produce bikedi and ntoba mbodi, two food products from Congo. Afr.J. Biotechnol., 4 (7): 689-696, DOI: 10.5897/AJB2005.000-3128

Kumar N. \& Quisumbing, A.R. (2010). Access, adoption, and diffusion: understanding the long-term impacts of improved vegetable and fish technologies in Bangladesh. IFPRI Discussion Paper 00995.

Maziya-Dixon, B., Dixon, A.G.O. \& Adebowale, A.R.A. (2007). 


\section{RURAL HOUSEHOLDS' PERCEPTION OF VITAMIN A BIOFORTIFIED CASSAVA AND ITS PRODUCTS}

Targeting different end uses of cassava: genotype variations for cyanogenic potentials and pasting properties. Int.J. Food Sci.Technol., 42: 969-976, DOI: 10.1111/j.13652621.2006.01319.x

Meijer, S.S., Catacutan, D., Ajayi, O.C., Sileshi, G W. \& Nieuwenhuis, M. (2015). The role of knowledge, attitudes and perceptions in the uptake of agricultural and agroforestry innovations among smallholder farmers in Sub-Saharan Africa. Int.J.Agric.Sustain., 13, 4054. DOI: $10.1080 / 14735903.2014$. 912493

Nestel P., Bouis H.E., Meenakshi J.V. \& Pfeiffer W. (2006). Biofortification of stable food crops. J.Nutr., 136: 1064-1067, DOI: 10.1093/oxfordhb/ 9780195397772.013.005

Nutrition-Federal Ministry of Health (2014). Health Sector Component of National Food and Nutrition Policy: National Strategic Plan of Action for Nutrition 2014-2019. Retrieved on $18^{\text {th }} \quad$ November, 2020 from https://www.health.gov.ng/doc/NSPA N.pdf. p.4

Nwokoro, O., Anyu, F.O. \& Eze, I.C. (2013). The use of microorganisms in increasing the protein yield of cassava (Manihot esculenta Crantz) peel wastes. J.Chem.Technol., 15(2): 112-115, DOI: 10.2478/pjct2013-0032

Obayelu, A.E., Olaleke, O.A., Oke, F.O. \& Oladeji, S.A. (2017). Economic analysis of cassava processing in Yewa South Local Government Area of Ogun State, Nigeria, NAAE, Annual NAAE Conference, October 16-19, Abeokuta, Nigeria, DOI: 10.22004/ag.econ.288303

Odediran O.F. \& Ojebiyi W.G. (2017). Cassava processors' willingness to utilize cassava peel for mushroom production in Southwest, Nigeria. IJAPR, 5(4): 86-93, DOI: 10.15739/ IJAPR.17.010
Olayemi, O.O., Ajanaku, A.O., Babatunde, R.O. \& Bashir, I.D. (2018). Acceptability of improved cassava varieties by cassava processor in Akinyele Local Government Area Oyo State. Scientific Research Journal (SCIRJ), 6(11): 61-67, DOI: 10.31364/SCIRJ/ v6.i10.2018.P1118584

Olatade, K.O., Olugbire, O.O., Adepoju, A.A., Aremu, F.J. \& Oyedele, P.B. (2013). How does farmers' characteristics affect their willingness to adopt agricultural innovation? The case of biofortified cassava in oyo state, Nigeria. AFFREV STECH: An International Journal of Science and Technology, 5(2): 59, DOI: 10.4314/stech.v5i2.5

Oparinde, A., Banerji, A. \& Birol, E., (2014). HarvestPlus Working Paper 13: Information and Consumer Willingness to Pay for Biofortified Yellow Cassava: Evidence from Experimental Auctions in Nigeria. Washington, DC: HarvestPlus.

Shanshan, L., Angela, N., Torbert, R. \& Wendy, S.W. (2010). Vitamin A equivalence of the $\beta$-carotene in $\beta$ carotene - biofortified maize porridge consumed by women. American J.Clin.Nutr., 92(5): 1105-1112, DOI: 10.3945/ajcn.2010.29802

Sofoluwe, N.A., Tijani, A.A. \& Baruwa O.I. (2011): Farmers perception and adaptation to climate change in Osun State, Nigeria. Afr.J.Agric. Res., 6 (20): 4789-4794, DOI: 10.5897/AJAR10.935

Wole-Alo, F.I. \& Okunlola, J.O. (2015). Utilization of modern cassava processing techniques among small holder rural women processor in Ondo state, Nigeria. JBAH, 5(12): 28-33.

World Health Organisation (WHO) (2017). Micro nutrients deficiency: vitamin A deficiency. www.who.int/ nutrition/topics/vad/en/ Retrieved on $5^{\text {th }}$ August, 2017. 